\title{
Geological Characteristics and Genesis of the Womagou Au-Cu Deposit in Qinghai
}

\author{
Chen Libiao, Chao Haide, Ren Wenkai \\ Qinghai Fourth Institute of Nonferrous Geological Exploration, Xining, China
}

Keywords: East kunlun metallogenic belt, Qinghai province, Womagou au-cu deposit, Deposit geology, Deposit genesis

\begin{abstract}
The Womagou Au-Cu polymetallic deposit is distributed in the Elashan area of Tibetan Autonomous Prefecture, Qinghai. It is located in the Zhiyi-Tongyugou Cu-Pb-Zn-Sn-Au-Barite IV metallogenic belt on the east side of the East Kunlun metallogenic belt, and is an important polymetallic mineralization area in Qinghai. There are a large number of $\mathrm{Cu}$ polymetallic mines in this area, and thus this ore belt has a very important position in China. This area is not only very complex in structure, but also shows the characteristics of multi-cycle evolution, and it belongs to a very important structural knot in west China. Au in the area has a good correlation with $\mathrm{Cu}$ and $\mathrm{Ag}$, presenting great mineralization potential. In the future, it is needed to strengthen the prospecting of related Ag deposits in this area.
\end{abstract}

\section{Introduction}

The ore body is produced in the Lower Middle Triassic Longwuhe Formation and is strictly controlled by the near-east-trending and north-east-trending fault structure. It is produced in a stratiform-like and lens-like shape. By now, $2 \mathrm{Au}$ ore (mineralized) bodies and $10 \mathrm{Cu}$ ore (mineralized) bodies have been discovered in the area. The deposits are mainly medium-low temperature magmatic hydrothermal type and structural alteration rock type. 45 minerals have been discovered in the area so far, of which one is large-scale, two are medium-sized and one is small-scale. Besides 7 placer gold-bearing ore sites, 31 ore sites and 10 mineralized sites were discovered. There are mainly 11 types of minerals, including $\mathrm{Cu}, \mathrm{Zn}, \mathrm{Sn}, \mathrm{Mo}, \mathrm{Au}, \mathrm{Ag}, \mathrm{Pt}, \mathrm{Fe}, \mathrm{Cr}, \mathrm{As}$, etc. The mineral deposits discovered so far are all produced in this area, such as the Suolagou Ag Mine and Saishitang $\mathrm{Cu}$ Mine. Structural alteration rock, continental volcanic eruption and marine hot water eruption deposition are the main genetic types of mineral deposits in the region, and this area has very superior metallogenic conditions. This paper mainly focuses on analyzing the geological characteristics of the deposit, hoping to provide a useful reference for prospecting in this area.

\section{Regional Geological Background}

The geotectonic structure of the deposit is located in the Elashan secondary orogenic belt, and it was formed due to the collision of the West Qinling orogenic belt and the East Kunlun orogenic belt at the end of the Triassic Period. The geological structure of this area has played a significant role in controlling the strata in the area. Affected by it, there are obvious fracture folds and unusually complex lithology and lithofacies changes in this area. The strata with the characteristics of fault blocks and shards are generally developed, and the tectonic mictite presents obvious stratum characteristics and a disorderly distribution. These characteristics are very similar to the stratigraphic structure of the orogenic belt. The main strata exposed in the area are the Jinshuikou Formation (Paleoproterozoic) and the Turgendaban Formation (Carboniferous Permian), Longwuhe Formation (Triassic), Elashan Formation and Gulangdi Formation. At the same time, the Yangqu Formation (Lower-Middle Jurassic), Neogene and Quaternary strata were also developed in this area. The intermediate-acid volcanic structure with normal sedimentary rocks is the lithological feature of the Turgendaban Formation, and eruptive deposition is its main feature, playing an 
important role in the ore-bearing layer. $\mathrm{Cu}$ mines such as Tongyugou developed in this formation. A large number of Longwuhe Formations are distributed in the east part of the Womagou area, mainly composed of carbonate rocks, sand slates and clastic rocks, which are important ore-bearing horizons in this area.

Since it was formed at different periods, the folds in this area are mainly composed of three parts. The tectonic folds with the characteristics of basement fault blocks occurred in the Caledonian stage. The short-axis anticline structure is the main feature, and the scale is small. Large-scale fold structures formed in the Indosinian stage. The folds with the characteristics of narrow slotted anticline and wide syncline are formed on the section. The monoclinic structure occurred in the Yanshanian stage. The fault structure is developed in the area, showing the distribution in the nearly north-south, northwest, nearly east-west and northeast directions. These faults not only connect with each other, but also present composite characteristics. Specifically, there are not only strike-slip lateral push and thrust surge but also strike-slip thrust. In addition, these faults also have unusually complex cutting features and present prominent oblique cuts, which severely control the stratum and the distribution of magmatic rocks and minerals in this area.

Magma activity is very prominent in this area, and has a very prominent multi-phase nature. The hotspring fault spreads north-north-west and separated it. The continental volcanic rocks (Late Triassic) are mainly distributed on the east side, and plutonic intrusions (the same period of volcanic activity) are distributed on the west side in large quantities, intruding the extruded rocks of the same period, and they have very prominent intrusive contact characteristics. These plutonic intrusions are very prominent in the Indosinian period. Diorite, quartz diorite and monzonitic granite are the main lithological features.

\section{Geological Characteristics of the Mining Area}

\subsection{Stratum}

The Longwuhe Formation (Middle and Lower Triassic) is widely exposed in the area, mainly composed of slate and sandstone. According to different lithological combinations, this formation is mainly divided into 3 lithological sections, namely the feldspar quartz sandstone section with slate, the lithic feldspar sandstone section, and the meta-quartz sandstone and the siliceous muddy slate section. The strata in the area are mainly feldspar sandstone with slate. Slate (shale and siliceous sand), argillaceous slate and feldspar quartz sandstone together constitute its lithological characteristics. The ore-bearing wall rocks in this area are mainly slate (shale and siliceous sand), with very prominent alteration types such as pyrite mineralization, azurite mineralization, arsenopyrite and malachite.

\subsection{Structure}

The syncline structure and compound anticline structure play a significant role in controlling the structure pattern in the region. The fold structure is particularly prominent in the area, and the fault structure is slightly not so prominent. At the end of the fold (compound) anticline structure, there are obvious fault structures developed, and the distribution shows the characteristics of nearly east-west direction, northwest direction and northeast direction, showing the characteristics of multiple stages, as shown in Table 1. The main faults in this area are the east-west extending fault structures, which were formed in the early stage and played a significant role in controlling the mineralization in the area. In terms of scale, the most prominent one is the F5 fault, with about $4.7 \mathrm{~km}$ exposed at the turning folds, and it played a significant role in controlling the intrusive rocks and mineralization alteration zone sb5 in this area. At the same time, this fault derives many secondary faults, which are mainly characterized by branching recombination and expansion and contraction. The characteristics of interlayer and cleavage and joints in the area are very prominent, especially in faults and turning fold areas. There are many interlayer fissures developed in the position of the wings of the folds, especially in the first-level sandrocks and slate parts of brittle rock formations, which are very closely related to the enrichment of ore bodies in this area. The 
various degrees of $\mathrm{Au}$ mineralization and $\mathrm{Cu}$ mineralization in this area are all produced in the north-east and east-west faults. The migration of ore liquid is completed through these fault structures and they play an important role in ore storage.

Table 1 List of Main Fault Structure Features in the Mining Area

\begin{tabular}{|c|c|c|c|c|c|c|c|}
\hline $\begin{array}{l}\text { Distribution } \\
\text { direction }\end{array}$ & No. & $\begin{array}{l}\text { Length } \\
\text { (m) }\end{array}$ & $\begin{array}{l}\text { Width } \\
\text { (m) }\end{array}$ & $\begin{array}{l}\text { Mineralization } \\
\text { alteration }\end{array}$ & $\begin{array}{l}\text { Material } \\
\text { composition }\end{array}$ & $\begin{array}{l}\text { Fracture } \\
\text { character }\end{array}$ & \begin{tabular}{l}
\multicolumn{2}{l}{ Control } \\
of ore \\
belt
\end{tabular} \\
\hline Near east-west & F5 & 4700 & $20 \sim 80$ & $\begin{array}{l}\text { Limonite } \\
\text { mineralization, pyrite } \\
\text { mineralization, } \\
\text { arsenopyrite } \\
\text { mineralization, } \\
\text { chalcopyrite } \\
\text { mineralization and } \\
\text { kaolinization }\end{array}$ & $\begin{array}{l}\text { Fractured } \\
\text { lithified slate, } \\
\text { sandrock }\end{array}$ & $\begin{array}{l}\text { Compression } \\
\text { (torsion) }\end{array}$ & sb5 \\
\hline North-west & F6 & 1400 & $10 \sim 20$ & $\begin{array}{l}\text { Limonite } \\
\text { mineralization and } \\
\text { carbonation }\end{array}$ & $\begin{array}{l}\text { Fractured } \\
\text { lithified slate, } \\
\text { sandrock, } \\
\text { limestone and } \\
\text { fault gouge }\end{array}$ & $\begin{array}{l}\text { Compression } \\
\text { (torsion) }\end{array}$ & \\
\hline North-east & F2 & 2400 & $18 \sim 60$ & $\begin{array}{l}\text { Limonite } \\
\text { mineralization, pyrite } \\
\text { mineralization, } \\
\text { arsenopyrite } \\
\text { mineralization, } \\
\text { chalcopyrite } \\
\text { mineralization, } \\
\text { silicification and } \\
\text { kaolinization }\end{array}$ & $\begin{array}{lr}\text { Fractured } & \\
\text { lithified slate, } \\
\text { sandrock and } \\
\text { fault gouge }\end{array}$ & $\begin{array}{l}\text { Compression } \\
\text { (torsion) }\end{array}$ & sb3 \\
\hline
\end{tabular}

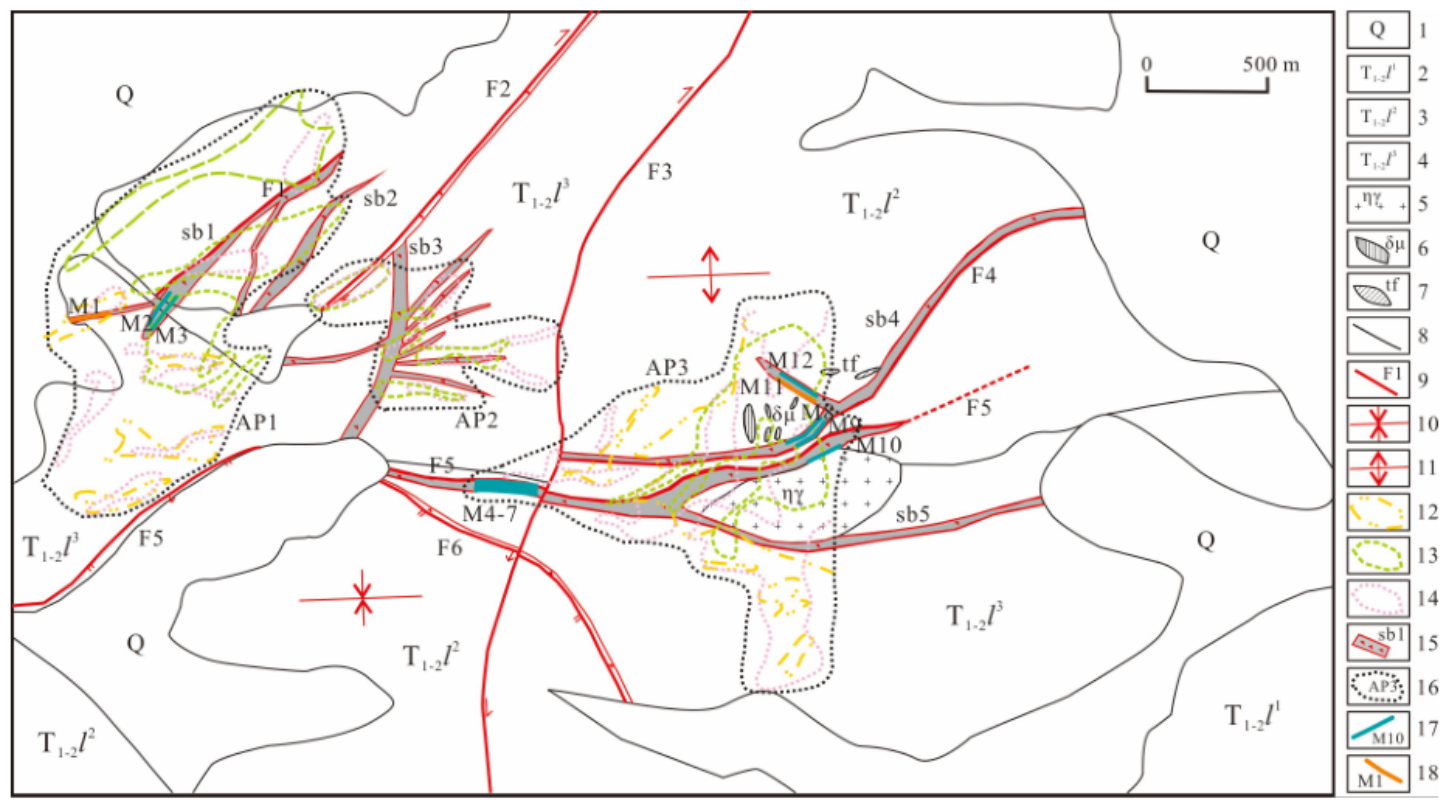

Fig.2 Geological Diagram of the Womagou Au-Cu Mining Area

1-Quaternary sediments; 2-gray-purple lithic feldspar sandrock section of Lower-Middle Triassic Longwuhe Formation; 3-meta-quartz mixed sandrock and gray-purple siliceous argillaceous slate section of Longwuhe Formation; 4-feldspar quartz sandrock splint slate section of Longwuhe Formation; 5-Monzonitic granite; 6-diorite porphyrite dike; 7-tuff dike; 8-geological boundary; 9-fault and No.; 10-syncline structure; 11-anticline structure; 12-Au anomaly; 13-Cu anomaly; 14-Ag anomaly; 15-mineralized alteration zone and number; 16-soil comprehensive anomaly and number; 17-Cu ore body and number; 18-Au ore body and number 


\subsection{Magmatic Rock}

Magmatic rocks are poorly developed in this area. The monzonitic granite presents a state of intrusion along the bedding at the F5 fault (the area on the east side of the mining area). It was formed in the Indosinian stage and was mainly produced with the lens-like characteristic, and the distribution direction is nearly east-west. Diorite porphyrite dikes are produced around this rock mass, and the distribution direction is near north-south. Diorite porphyrite with vein-like characteristics in the fracture zone is distributed in a local area, accompanied by certain $\mathrm{Cu}$ mineralization. According to the analysis of the data in this area, the anomalies consistent with this rock mass are mainly $\mathrm{Cu}$ and AP3Au soil anomalies, as shown in Figure 1. The Au-Cu ore body was found around the rock body. Related analysis suggests that the mineralization in the area is very closely related to the rock body and that it is the main mineral source and heat source in the area. There are some small tuff lenses around the monzonitic granite lens, with obvious characteristics of volcanic eruption facies.

\section{Deposit Features}

\subsection{Orebody Characteristics}

By now, 5 mineralized alteration zones have been discovered in the area and separated by F3 fault, mainly including sb1, sb2, sb3, sb4 and sb5. The first three groups are mainly distributed on the west side of the F3 fault, showing a north-east distribution, and the latter two groups are on the east side of the F3 fault, showing a nearly east-west distribution. In the structural alteration zone in this area, there are mineralized alteration zones with a length range of $0.8-4.5 \mathrm{~km}$, a width range of $20-60 \mathrm{~m}$, and a maximum width of $150 \mathrm{~m}$. They are inclined to the north and northwest at an angle of $30 \sim 80^{\circ}$. The soil anomalies and mineralization alteration have similar anomalous characteristics, and mineralization belts (sb1, sb2, sb3) are distributed in soil anomalies AP1 and AP2. Two Cu ore bodies were exposed by the project in the zone, and at the same time one Au ore body was controlled. There are two mineralized belts (sb4 and sb5) in the AP3 soil anomaly. $8 \mathrm{Cu}$ mineralizations and $1 \mathrm{Au}$ mineralization have been circled. The characteristics of molecular recombination and swelling and shrinking appear obviously in the direction of the mineralization zone. At the same time, the secondary faults are distributed on the belt, and the structure plays a significant role in controlling the ore bodies in the area. The output characteristics are mainly lens-like and stratiform-like, and the characteristics of the ore body are analyzed as follows:

M1-M3 Cu and Au ore (mineralized) body are on the southern side of the mineralization zone sb1.The distribution is stratiform-like and lens-like, inclined to the direction of $315-325^{\circ}$, and the angle is in the range of $75^{\circ}$. The surface of M2 and M3 is controlled by STC701 and CYP1 trench engineering, with a length of about $200 \mathrm{~m}$ and a thickness of $1.98-5.94 \mathrm{~m}$. SZK701 borehole control its deep part, with a thickness of about $2.97-5.63 \mathrm{~m}$, reaching the average Cu grade of $0.28 \times 10^{-2}$ and $0.3 \times 10^{-2}$. STC1101 controls M1 with a length range of $80 \mathrm{~m}$ and a thickness of $0.99 \mathrm{~m}$.

M4-M7 Cu ore (mineralized) body are in the mineralized alteration zone sb5. They are lens-like and layered, which is inclined in the direction of $5-20^{\circ}$, and the angle is $50-80^{\circ}$. The TC001 trough has obvious control over its formation, with a length of $180 \mathrm{~m}$ and a thickness of $0.98 \mathrm{~m}$.

M8-M10 Cu ore (mineralized) body are in the mineralized alteration zones sb4 and sb5. The distribution is layered, showing the occurrence characteristic of $320^{\circ} \angle 80^{\circ}$. The ETC02 trough controls the length of $2000 \mathrm{~m}$. The thickness ranges of the ore bodies M8, M9 and M10 are respectively $0.90 \mathrm{~m}, 1.80 \mathrm{~m}$ and $0.84 \mathrm{~m}$, and the grades are $1.25 \times 10^{-2}, 0.74 \times 10^{-2}$ and $0.65 \times 10^{-2}$ respectively.

M11 and M12 Cu-Au ore (mineralized) bodies are in the mineralized alteration zone sb4, and the distribution is lens-like, with the occurrence characteristic of $350^{\circ} \angle 83^{\circ}$. The length of $150 \mathrm{~m}$ and the thickness of $0.49 \mathrm{~m}$ are controlled by the ETC01 trench, reaching $1.6 \times 10^{-6}$ Au grade and $0.5 \times 10^{-2}$ Cu grade. 


\subsection{Ore Characteristics}

Sulfide minerals such as chalcopyrite, arsenopyrite and pyrite are the main metal minerals in the ore, and feldspar, calcite and quartz are the main gangue minerals. The higher the content of limonite, arsenopyrite and pyrite, the more obvious the mineralization of gold and copper. allotriomorphic granular irregular structure and idiomorphic granular structure are the main ore structures, especially the former. Fractured and infested structures are the main structural features of the ore in this area, and the latter is especially common.

\subsection{Features of Wall Rock Alteration}

Meta-feldspar sandrock, argillaceous calcareous slate, silty slate and siliceous slate are mainly gray-green, brown and red, and they are the main wall rocks of $\mathrm{Au}$ and $\mathrm{Cu}$ mines. Mineralized alteration is very prominent around the ore body, and the further away from the ore body, the weaker the mineralization characteristics. Limonite mineralization, jarosite mineralization, and arsenopyrite and pyrite mineralization are the main features of wall rocks. Among them, the most prominent is the alteration characteristics of pyrite mineralization, arsenopyrite mineralization and chalcopyrite mineralization. The gradually shallower ones are azurite mineralization and limonite mineralization, and then malachite mineralization and jarosite mineralization. The formation of $\mathrm{Au}$ ore bodies is closely related to pyrite mineralization and arsenopyrite mineralization. The formation of $\mathrm{Cu}$ ore bodies is closely related to chalcopyrite mineralization. The distribution of alteration types such as carbonatization and siliconization is phased, followed by sericitization, kaolinization and argillization. According to the analysis of the characteristics of the Au-Cu ore body, the most favorable zone for mineralization occurs in the structural alteration zone with strong alteration.

\section{Analysis of the Genesis of the Deposit}

The orogeny formed by the collision of the East Kunlun orogenic belt and the West Qinling orogenic belt has a great influence on the strata in the region. The tectonic magma activity became more and more intense under the strong compression of the two, and the ore-forming materials and heat sources in this area all came from the influence of the magmatic activity. Minerals were transported to favorable mineralization locations through the channels of these deep and large fractures. During this process, the ore-forming elements $\mathrm{Au}$ and $\mathrm{Cu}$ gradually enriched in the Longwuhe Formation, and there was a very prominent metasomatism. At this stage, a large amount of ore liquid was gradually enriched, and the ore was enriched under favorable conditions of mineralization geology. In the fractured alteration zone, lens-like and stratiform-like mineralized bodies are produced. The north-east and east-west fractured structures in this area have obvious control effect on its formation, suggesting that its structure control features are very obvious. Carbonatization, limonite mineralization, kaolinization, pyrite mineralization, and siliconization present strong alteration, with prominent hydrothermal alterations. Combining the mineralization characteristics of the Kuhai $\mathrm{Hg}$-Au deposit, a comprehensive study and analysis of the deposit showed that the mineralization of the deposit is mainly composed of structurally altered $\mathrm{Cu}-\mathrm{Au}-\mathrm{Ag}$ deposits and hydrothermal filling metasomatic $\mathrm{Pb}-\mathrm{Zn}$ deposits. The late Indosinian stage is the main period of the mineralization.

\section{Conclusion}

The source layer in this area mainly belongs to the Longwuhe Formation of the Womagou $\mathrm{Au}-\mathrm{Cu}$ polymetallic deposit. The ore-containing and ore-controlling structures in this area are mainly fault structures, which are distributed in a north-east and near-east-west direction. The heat source in this area is mainly monzonite (Indosinian). Through comprehensive analysis, it is judged that structurally altered rock type $\mathrm{Cu}-\mathrm{Au}-\mathrm{Ag}$ deposits and hydrothermal filling metasomatic $\mathrm{Pb}-\mathrm{Zn}$ deposits are the main deposit types in the area, and that the late Indosinian stage is the main mineralization period of the mine. This area has very superior Ag mineralization conditions. The characteristics of oxidation leaching are very prominent in the surface $\mathrm{Pb}$ and $\mathrm{Zn}$ elements, so that 
the area has abundant high-intensity abnormal characteristics. In the past, there were great deficiencies in the process of prospecting in the area due to the negligence of $\mathrm{Ag}, \mathrm{Pb}$, and $\mathrm{Zn}$ elements. Therefore, the following geological prospecting work should strengthen the research work of Ag deposits and the sources of Pb-Zn anomalies.

\section{Acknowledgment}

This research was financially supported by China Geological Survey: "Investigation of Geology and Mineral Resources in Sunan--Dachaidan Area in Qilian Metallogenic Belt”(No. DD20160012)

\section{References}

[1] Yan Ning, Li Shehong, Lu Zhiping, et al. Metallogenic Characteristics and Genesis of Suolagou copper Multi-Metallic Deposit in Xinghai County, Qinghai Province[J]. Geotectonica et Metallogenia, 2011, 35(1): 161-166.

[2] Wang Xiaoyun, Yang Baorong, Huo Haiqing, et al. Accommodating ore condition and mineralization rule research of Ag-Pb-Zn deposit in Ela mountain pass Qinghai province [J]. Gold Science and Technology, 2007, 15(1): 41-44.

[3] Ding Zhengjiang, Sun Fengyue, Li Bile, et al. Geological Characteristics and Prospecting Potential of the Kuhai Mercury Deposit in Qinghai Province [J]. Geology and Exploration, 2010, 46(2): 198-206.

[4] Ding Zhengjiang, Sun Fengyue, Li Bile, et al. Study on Forming Conditions and Metallogenesis of Kuhai Mercury Deposit, Qinghai Province [J]. Journal of Jilin University(Earth Science Edition), 2009, 39(1): 9-15.

[5] Guan Bo, Su Shengnian, Yang Qingyun, et al. Analysis on Gold Prospecting Potential of Kuhai Area in Qinghai Province [J]. Gold Science and Technology, 2012, 20(3): 35-39.

[6] Li Shanping, Xie Zhiyong, Huang Qinghua, et al. Mineralization and prospecting potential of Indosinian terrestrial volcanic rocks in Orashan area, Qinghai [J]. Northwest Geology, 2012, 45: 49-52.

[7] Zhou Xiaozhong, Fan Likun, Shen Yongsheng. Geological and Geochemical Characteristics of Gouli Area and its Prospecting Ori-entation [J]. Gold Science and Technology, 2009, 17(3): 17-19.

[8] Luo Zhaohua, Ke Shan, Cao Yongqing, et al. Late Indosinian mantle-derived magmatism in the East Kunlun [J]. Geological Bulletin of China, 2002, 21(6): 292-297.

[9] Chen Sulong, Ma Guodong, Li Yulian, et al. Geological Characteristic and Origin Analysis for Walegen Gold Deposit in Zeku County,Qinghai,China [J]. Northwest Geology, 2015, 48(4): 168-175. 